\title{
PREFACE
}

Proper forest management must take account of and balance many factors; some have direct positive or negative links with human activity (e.g. cultivation, fires), and some are more closely connected with the ecology of the system, such as environmental features and disturbances indirectly caused by anthropogenic activities through atmospheric deposition and pollution.

These problems are more marked in a geographically complex country like Italy, which has a variety of environments (Mediterranean, Apennine and Alpine) with distinct differences between them, reflected in the vegetation types. A further characteristic of our country is its high density of population and productive activities, which has resulted in the deforestation of the areas most suited to agriculture and industry, and encouraged the growth of forests which can be exploited by man.

The requirements demanded by the rational use and management of forest resources, together with the concern arising in the seventies over the impact of atmospheric pollution on the state of health of woodlands, prompted a number of studies and interventions sponsored by the Ministry of Agricultural and Forestry Policy, which are described in the first article of this volume. Other studies on the forests were begun, and continue, under the aegis of the Forestry Departments of some Regions, such as Tuscany and Lombardy, and the Autonomous Provinces of Bolzano and Trento. Some of these projects are run in the framework of European Community programs, and have made a useful contribution to our knowledge of the respective ecosystems, laying the foundations for long-term monitoring. Some of the results of these activities are included in this volume.

A more comprehensive research effort to investigate the different ecological and geographical conditions in Italy was dictated by the obligations set out in the Convention on Long-Range Transboundary Air Pollution, established by the United Nations/Economic Commission for Europe, and its projects, two of which are the International Co-operative Programme on assessment and Monitoring of Air Pollution Effects on Forest (ICP Forests) and the International Co-operative Programme on Integrated Monitoring of Air Pollution Effects on Ecosystems (ICP IM), and the EU Scheme for Forest Protection against Atmospheric Pollution. The aims of ICP Forests and the EU Scheme are to acquire knowledge on the spatial and temporal variations of forest conditions in Europe and on the relationships between forest condition, air pollution and other stress factors.

To implement these projects and extend the scope of ongoing projects, the National Programme for Forest Ecosystems Control CONECOFOR was started in Italy in 1995 in the framework of Level II forest monitoring (Regulation EC $\mathrm{n}$. 1091/94). Twenty eight permanent monitoring plots have now been installed and are at present operating all over Italy, in the most important forest biocenosis in the country. Analyses include crown condition assessment, chemical composition of the soil, leaves and needles, atmospheric deposition and pollutants, tree growth assessment, meteorology and ground vegetation assessment. The project is co- 
ordinated nationally by the National Focal Centre (Ministry for Agricultural and Forestry Policy - National Forest Service), in close collaboration with some Regional Administrations, which are responsible for monitoring some of the permanent plots, applying harmonized methods. The methodologies used in the different studies are in strict agreement with those prescribed by the related EU Regulations and recommended by the Programme Co-ordinating Centre of ICP Forest; results are validated at a national level and sent yearly to the EU advisory institution in charge of the international data management. The national studies and monitoring are co-ordinated by research institutions and universities, which provide for analyses, data collection and evaluation at a national level. Scientists from these institutions form a National Expert Group which assists the National Focal Centre (NFC), to analyze the data, interpret the results, and monitor the evolution of the Italian situation; the National experts support the NFC in the scientific management of the Programme and in participating to the International Expert Panels and Working Groups.

Seven years after its inauguration, CONECOFOR is now one of the larger environmental programs in Italy, uniting administrations and scientists in the effort to understand and, if possible, to control forest evolution and management. The great amount of measurement and information required, the monitoring nature of some of the studies, and the extent and variety of the expertise involved, make this a valuable project not only for forest ecosystems, but for a wider environmental understanding which includes air and waters. Furthermore, the permanent contacts and dialogue established with the major European institutions and scientists to assure the highest quality of measurements and data evaluation make participation in the project a stimulating opportunity and a challenge of excellence for people and institutions taking part.

The present volume is an attempt to summarize some of the components of Italian forest research, including the activities carried out by Regional and Provincial Administrations, those performed in the framework of the CONECOFOR project, and the results of collaboration with European institutions. It is surely a positive sign that the volume is published concurrently with the first meeting of an EU/ICP Forest Experts Panel held in Rome; besides recognizing Italian participation in the European team, this also offers a premise for more comprehensive co-operation between Italian and European scientists working in environmental studies, which are aimed both at understanding the processes involved and choosing the best management strategies to be implemented.

\section{Bruno Petriccione}

Ministero per le Politiche Agricole e Forestali, Corpo Forestale dello Stato, Servizio CONECOFOR, Roma

Rosario Mosello, Aldo Marchetto

C.N.R. Istituto per lo Studio degli Ecosistemi (ISE), Sezione di Idrobiologia ed Ecologia delle Acque Interne, Verbania Pallanza 